\title{
Integrated Undergraduate Management Education: An Informal Benefit / Cost Analysis
}

William L. Casey, Jr., (Email: casey@babson.edu ), Babson College

\begin{abstract}
This paper seeks to contribute to the literature of management education by evaluating assessment data on Babson College's integrated undergraduate management core program (IMC). Transitions from functionally isolated curricula to more integrated alternatives involve both benefits and costs, accruing to faculty, students and sponsoring institutions. The relative benefits and cost of the Babson program are weighted based on recent assessment initiatives at the college.
\end{abstract}

\section{Introduction}

61 ne of the important trends in higher education over the past two decades has involved initiatives to promote across-the-curricula integration. Innovations in the delivery of management education have been particularly responsive to the criticism contained in the path-breaking study of the American Assembly of Collegiate Schools of Business (AACSB) that business schools in the 1980s were failing to integrate across functional areas (Porter \& McKibbin, 1988). Accordingly, courses were being delivered in isolated functional packages with the unrealistic expectations that students on their own would be capable of establishing curriculum linkages.

In the 1990s and early 2000s, criticisms of functionally isolated curricula in higher education continued (e.g. Boyer, 1990; Harrigan, 1990; Boyatizis, Cowan \& Kolb, 1995; Zolner, 1996; Porter, 1997; McKinney \& Yoos, 1998; Dodd, Brown \& Benham, 2002). Critics urged institutions of higher learning, including business colleges, to redesign curricula for the purpose of preparing students for today's complex societal and organizational environments by teaching them to think and learn integratively.

Recent examinations of curricular reform in business schools reveals a sensitivity to criticism and a responsiveness to change on the part of many. In seeking to enrich the learning experience of students through the redesign of curricula, different approaches have been adopted, e.g. the University of Denver model where modular courses are designed around traditional management skills replacing a more functional curricula (Slater, McCubbrey \& Scudder, 1995), the University of Minnesota model where integrated learning is achieved through the use of cross-disciplinary teams of faculty (American Assembly of Collegiate Schools of Business, 1995), the Wharton School model where integration is sought through the extensive use of cross-disciplinary cases (Elliott, Goodwin \& Goodwin, 1994) and the University of Idaho model where integration is based on the creation of a common body of knowledge linking the various business functions in the curriculum (Pharr, 2000). 
Efforts to break down functional walls in designing more integrated and holistic business school curricula have been launched at both the undergraduate level (Geiger \& Dangerfield, 1996; McKinney \& Yoos, 1998; Pharr, 2000; Miller, 2000; Hartenian, Schellenger \& Frederickson, 2001; and Palocsay, White \& Zimmerman, 2004) and at the MBA level (Van Fleet, 1995; Schlesinger, 1996; McLeod \& Cotter, 1999; and Latham, Latham, \& Whyte, 2004).

Included among the business colleges that have redesigned undergraduate and MBA programs promoting integration at both levels is Babson College of Wellesley, Massachusetts. Schlesinger (1996) examined the college's efforts in the mid 1990s to integrate its MBA curriculum through the adoption of cross-functional modules, and Bliss and Porter (2000) described Babson's more recent initiatives in restructuring its undergraduate management core curriculum, a critical evaluation and review of which is the central focus of this paper.

During the fall semester of 1997, Babson College launched a new undergraduate management core program, involving a multi-disciplinary, integrated, team-teaching pedagogy. The disciplines included economics as well as those functional areas in management (accounting, finance, marketing, operations, organizational behavior) typically taught as core courses in traditional undergraduate management curricula. In addition, topics in business strategy, business law, international business and entrepreneurship were incorporated.

The program, recently modified, was offered from 1997 to 2003 in a three-semester sequence, extending from the first semester of sophomore year through the first semester of junior year. As an economist on the Babson faculty, I have been involved in all aspects of the program, (planning, coordinating, teaching, reviewing) since its inception.

The purpose of this article is to evaluate the success of the program using assessment data gathered from both program faculty and students. The attempt will be made to weigh the relative benefits and costs occurring to participating faculty and students.

In the literature of management education, there have been extensive discussions of efforts that business schools have made at both undergraduate and MBA levels to integrate across functional disciplines. Given the length of time that many of these programs have been in place, it is now time to move beyond the descriptive level of examination and to attempt to evaluate the keys to program success, the obstacles to success and the areas of promise and frustration. It is the purpose of this article to provide some insight in this regard by assessing the six-year Babson experience, beginning with a program description and followed by a program evaluation.

\section{Babson Program Overview}

In developing this multi-disciplinary, integrated approach to management education, the Babson program, named the Intermediate Management Core (IMC), was designed to develop in students a capacity for rigorous, critical thinking and for effective decision-making. The program sequencing employed the analytical paradigm of description (IMC1), analysis (IMC2) and synthesis (IMC3). The first semester was designed to promote student ability to identify, describe and summarize complex information/data relating to the nature of business organizations, the competitive environments in which they operate as well as the function of people and processes within those organizations. Students in IMC1 were required to take four courses during the semester including three disciplinary streams and a capstone seminar. One stream integrated accounting and finance, a second integrated business operations and organizational behavior and a third combined microeconomics and marketing. 
Following the establishment of this foundation during the fall semester of sophomore year, students then moved on in the spring to IMC2 during which time the traditional management disciplines were revisited at a loftier level of analysis. The focus here was on a rigorous examination of managerial problems and situations, using the descriptive backdrops to help identify potential problems, while introducing analytical tools to identify what options firms may have in addressing these problems. The implications of using alternative policy options were examined as well.

Finally, during the fall semester of junior year, the IMC curriculum was structured to hone the skills of students in solving business problems in complex settings under conditions of ambiguity through cases and exercises. As students proceeded through the three-semester sequence, the level of analysis was elevated and the pedagogical approach changed somewhat from lecture/discussion to case analysis to field work. The anchor of the program, however, remained constant throughout; i.e., the development of decision-making skills.

In designing the program, the Babson faculty identified the sequence of steps in the decisionmaking process that managers should follow in the real world and that students were expected to follow in classroom simulations. We used the acronym LIFERAFT to summarize the steps in the process. In simulations, students are instructed that they must:

- Locate the business situation that calls for a decision-- strong research, assessment, assembly and communication of facts are essential to any decision making.

- Identify-- interpret the description you have assembled and identify issues and opportunities.

- Fill in the details-- determine what additional information and analysis are necessary to evaluate the situation.

- Extract the implications-- diagnose the problem and determine the options.

- Reality check-- check on the viability of the options.

- Act-- choose and implement.

- Feedback-- assess the effectiveness of the solution.

- Test-- use the data, information and feedback to test your assumptions, logic, analysis and conclusions.

\section{The IMC Program: Expectations}

The IMC program was launched in 1997 with the expectation that several significant benefits would accrue to program faculty, to students and to the college, but that there would be tangible and intangible costs as well.

\section{Expected Student Benefits}

The early expectation was that students participating in the program would enjoy enormous benefits. Traditionally, management faculties have taught their disciplines alone in the classroom with little or no day-to-day contact with colleagues concerning the coordination and timing of curriculum content. In such a system, the burden of curriculum integration (seeing linkages and interrelationships among the management disciplines) falls on the students, which is typically well beyond the capabilities of college sophomores and juniors. In the absence of success in this regard, students end up seeing their management education as isolated bits and pieces rather than an integrated whole. In the integrated system, the burden of establishing curriculum linkages falls on the faculty where it belongs.

The IMC program was designed to eliminate unnecessary content overlap and redundancies. We discovered, for example, that prior to the curriculum restructuring, the basics of price elasticity of demand 
were taught by both economics and marketing faculty from scratch, unaware that time was being wasted in the classroom. Close coordination in IMC was designed to eliminate redundancies, freeing up time for additional course content and reinforcing exercises with obvious benefits accruing to students.

In a related area, we also discovered that, even when foundation material was covered properly in non-integrated programs, the use of different language or labels in different disciplines often confused students. Economists talked about "marginal" costs and accountants made reference to "incremental" costs without informing students that these were two names for the same measure. In IMC we either standardized the language, or if different terms were used, students were notified.

Also, since managerial decision making in industry tends to be multi-faceted and not artificially confined to functional disciplines, and since effective management requires cross functional insights, the IMC program was designed to simulate the decision-making processes in business and better prepare students for creative careers in management.

Regardless of the capabilities of business students, the reaction in the business world to integrated curricula, corporate recruiters included, was expected to be very positive. The planning process at Babson included input and reactions from college alumni and other members of the business community. The perception among most business leaders is that integrated curricula can be effectively designed to simulate the managerial responsibilities in entry-level positions and beyond. The expectation here was that graduating students would benefit in their job searches because of this positive attitude about curriculum reform among corporate and other recruiters.

\section{Expected Faculty Benefits}

As indicated above, the IMC program was designed to eliminate curriculum redundancies. This would benefit faculty by freeing up time for additional course content. Review of our undergraduate management core prior to the reforms revealed unintentional gaps as well as redundancies in the curriculum. Professors of more advanced courses were frequently frustrated in discovering that certain foundation material was either not covered in earlier courses or was not covered in a timely fashion. Accordingly, these advanced courses had to be watered down because of necessary, but belated, insertion of foundation material. IMC was designed to eliminate this problem.

Team teaching was a key feature of IMC. It was expected that this would promote a rich learning experience for management faculty and that the benefits of this experience would resonate in the classroom. For example, I should be able to do a better job teaching my upper-level courses in economics with a more comprehensive understanding of the management core background that my students are receiving. I should do a better job building on a framework that I now thoroughly understand. Interacting with students should be easier now that I understand where they are coming from and what they have been exposed to pedagogically to date.

It was also expected that the new integrated program would create new opportunities for management faculty to participate in cross-disciplinary research collaborations. Viable projects hopefully would flow from course planning efforts particularly because the focal point of planning tends to be the search for cross-disciplinary linkages and synergies. Collaborations among Babson faculty members would promote an efficient division of labor, in which one faculty partner may bring quantitative skills to the collaboration and the other practical field experience. The recent proliferation of associations and journals that specialize in multidisciplinary research has certainly spurred this type of research, complementing IMC-type programs. 
Finally, since the IMC curriculum was designed as a better match for the business experience, the expectation was that more consulting opportunities would open up in the corporate world for faculty participating in the program.

\section{Expected Institutional Benefits}

Regardless of the actual value added resulting from the process of integrating the undergraduate management core, the expectation was that business world reactions, corporate recruiters included, would be very positive. This proved to be the case. The early planning process included inputs and reactions from college alumni and other members of the business community. The perception among most business leaders was that IMC-type programs are ideally designed to prepare students for entry level positions and beyond. The image of our college was significantly improved initially because of our willingness and ability to promote this type of structural curriculum reform.

The image of the business college was enhanced as well in the community of U.S. business schools. Credit was given for the effort that Babson made in dealing with internal resistance to change. Not surprisingly, faculty elsewhere were more aware and sensitive to the costs of the program (evaluated below) than in the case of the business community. However, would this positive image be sustainable as IMC students entered the world of management in competition with more traditionally educated business students?

\section{Expected Student Costs/Risks}

One concern arising from the need to capture time in IMC in order to build in integrated exercises and casework was the extent of resulting opportunity costs. Some standard, introductory, disciplinary material in the management core had either to be postponed or eliminated. The expectation was that students might miss some key concepts needed to advance in disciplinary study. Attempts were made to include some of this material in mezzanine-type, intermediate course (containing material needed for advanced study but deleted from introductory courses), but would this be sufficient to bridge the gap?

There was also concern that the uniqueness of the college's new curriculum would create another potential problem for students, particularly those who may seek to transfer out of the college after sophomore year or beyond. We questioned the transferability of such unique cross-functional courses as "Understanding the Firm and the Market" or "Understanding the Organization". Clearly, the Babson student seeking to leave the college would be at risk of losing credits and tuition money in the process.

In the economics department, our concern about the restructuring of the curriculum at the college extended beyond the above. Traditionally, the teaching of economics at business colleges involves a dual mission. On one hand, economics provides a theoretical and conceptual foundation for the study of the functional disciplines of management but, as a social science, it also addresses important social and political issues, thereby contributing to the liberal education of undergraduates. The rigors of the IMC program at Babson forced the economics department to trade-off some coverage of the latter (at least at the principles level) in order to provide more support for the former. Accordingly, are economic departments in innovating management colleges now doing a better job preparing students to be managers, while at the same time doing a poorer job preparing them to be enlightened citizens? If so, is this an acceptable trade-off?

Finally, it was expected that an integrated management core would involve more work for students. Students would tolerate the extra work if the appropriate rewards, such as an improved learning 
experience and enhanced job prospects, emerged in the future. Of course, if the learning experience proved not to be positive or if the improvement in the quantity and quality of entry-level job opportunities for graduates did not materialize, it was expected that student attitudes about the program and its heavy work commitment would quickly become negative.

\section{Expected Faculty Costs/Risks}

Participating in a program that requires faculty to teach beyond the normal boundaries of traditional disciplines obviously involves heavy time commitments in the areas of course preparation and student evaluation. It was also expected that faculty members, participating in the program, would discover hidden opportunity costs beyond the obvious. The complexity of IMC-type programs require tight coordination and frequent meetings. Would faculty research be crowded out during semesters of IMC participation because of the heavy time commitment and the disruptive effects of dealing with crises (both major and minor) that are the by-products of the program's complexity? Would IMC be a doubleedge sword with reference to research? Would it open up windows of opportunity for cross-disciplinary research but steal some of the time needed to exploit the same?

There was also the concern that the Babson-specific nature of the IMC program would create related vulnerability for young faculty. The college rewards those faculty who remain at the college and are willing to make a heavy teaching and program service commitment at the expense of research. However, these rewards may not be transferable externally for the young faculty who choose to leave Babson. Publications remain the most transferable "capital" in higher education and should not a young academic think twice about trading off too much research time regardless of the internal reward system at the college?

\section{Expected Institutional Costs/Risks}

Program costs were expected to be very high particularly in the case of those segments of IMC which were team-taught. Two faculty members were present at all times in the classroom effectively doubling the costs of delivering this foundation material.

Additional costs arose because of the complexity of the program, requiring a heavy commitment of faculty resources to the planning and review processes. Several faculty members received reduced course loads over the year to free up time for planning. Additional faculty obviously had to be hired to cover courses normally taught by the planning staff. There was an early concern that the heavy cost of administering and staffing such programs, unless effectively controlled, could lead to a cutback in resource commitments elsewhere that potentially could compromise quality. Also there was early concern that if the current trend toward more integrated teaching in business colleges and more multidisciplinary associations and journals does not continue, the Babson program could potentially become more isolated. This might diminish the marketability of the college as well as the research output of its faculty. Also, if the costs accruing to participating faculty prove to outstrip the aforementioned benefits, problems of faculty recruitment and retention could arise.

Finally, if the expected growth in the quantity and quality of entry-level job opportunities for graduates educated in the integrated management core fail to materialize, student retention and student recruitment could potentially become a problem. Obviously, the college assumed some significant risk in launching this program six years ago.

The IMC Program: An Assessment 
Following the 2002-2003 academic year, IMC students and faculty were polled in an attempt to assess the success of the first phase program (IMC1). The response rate was statistically satisfactory for both groups (30\% of eligible students and $64 \%$ of eligible faculty members). The results of the survey are summarized in Tables 1-6 in the Appendix.

Although the survey guide was not designed to cover all aspects of the benefit/cost framework outlined earlier in the paper, some light was shed on the relative value of IMC1 through the eyes of both students and faculty who had recently completed this foundation semester.

\section{Student Assessments}

Student reactions to the IMC1 experience were generally positive, particularly in reference to the perceived value of the program in imparting an understanding of the key concepts of the functional disciplines of management education. We identified these key concepts which are summarized in Table 1. Student reactions (Table 1) helped allay our concerns that these basic concepts might be "crowded out" of the program because of the need to find time for integrated case and exercises. As revealed by Table 1, a majority of responding students believe that they exited IMC1 retaining an understanding of basic managerial concepts. Notable exceptions to this (concepts that apparently fell through the program "cracks") were the "product-process matrix" and "service processes."

Interestingly, student reactions to the effectiveness of integrated work in the program were quite mixed (Table 2). On one hand, a significant majority of the students reported that IMC1 (1) increased their understanding of the relationships and linkages among management disciplines, (2) promoted their abilities to address multidisciplinary management issues and (3) enhanced their abilities to identify, describe and summarize complex material about organizations, people and production processes. On the other hand, the program case work received a more negative evaluation from students.

Two plausible reasons may be given for this seeming contradiction. Much of the integrative work on IMC1 took place on regular class days by teams of faculty from two disciplines, e.g. microeconomics and marketing. Based on student feedback, these faculty teams were successful in promoting twodiscipline integration. On the other hand, there were special case days during which the objective was to demonstrate the synergies and linkages among six foundation disciplines. This apparently produced complexities for students who were expected to extend their thought processes across six disciplines. Furthermore, the complexity and uniqueness of the integration required tailor-made cases, which increased the work burden of the faculty and produced case products which had to be written quickly and which were not particularly polished.

As reflected in Table 3, IMC1 students were generally positive in their assessment of how well the program prepared them for the future, both in reference to upper-level undergraduate requirements and future career/internship aspirations. It should be mentioned that the latter opinions were based on more than pure speculation. Through the college's formal "coaching” program, Babson students do have contact with future prospective employers and do receive feedback on the match between educational experiences and career aspirations.

Finally, since Babson has a competency-based curriculum, it was important to test student reactions to the quality of the IMC1 experience in developing these competencies (summarized in Table 4). Again, student feedback was generally positive, particularly in reference to the importance of the program in teaching teamwork, leadership, the ability to organize, synthesize, evaluate and interpret 
information as well as the ability to bring a high level of business expertise to the workplace or to society in general.

Interestingly, student comments about IMC1 were most negative in the two competency areas, i.e. business ethics and the provision of an international/multicultural perspective, that rank highest in the college's priority list for current and future curriculum reform.

\section{Faculty Assessment}

The faculty evaluation of the IMC1 produced general positive results, although there were some significant areas of disagreement both in reference to program costs/benefits for students and for faculty.

A significant majority of the participating program faculty concluded (Table 5), that the IMC1 experience (1) did serve to demonstrate to students the important linkages among the several functional management disciplines in the program, (2) did closely mirror actual conditions and processes in the business world, (3) did prepare students effectively for the upper-level study of management and (4) was an effective way of teaching functional skills.

On the negative side, some disagreements were visible in the survey, relating to (1) the effectiveness of the program case work in teaching decision-making skills, (2) the program's success in standardizing the labels and language used in different disciplines for the same concepts and (3) the effectiveness of the program design in achieving integration without curriculum fragmentation.

Cynics would say, of course, that the best way to avoid fragmenting the management core would be to return to the traditional method of teaching functional skills in a separate functional course. The costs of retreating would be viewed by the college as excessively heavy, however. Current priorities in the area of curriculum reform involve the development of integrative cases, exercises and other materials that are better designed to impart decision-making skills and to integrate without fragmentation.

Interestingly, faculty perception of how they were affected professionally by the IMC1 experience was also mixed (Table 6). The perceived benefits were mostly on the teaching side. A significant majority of the participating faculty indicated that the program (1) was a valuable learning experience through the stretching of responsibilities beyond the normal boundaries of traditional disciplines, (2) did improve upper-level course teaching by providing an overall curriculum overview, (3) did improve teaching through exposure to pedagogical styles and skills practiced in other disciplines and (4) did improve faculty ability to interact with students based on a better understanding of the total curriculum mission.

On the other hand, a majority of responding faculty indicated in the survey that the program was costly particularly in reference to time commitments in out-of-class coordination activities. Furthermore, for the majority, IMC1 participation did not significantly spur productivity in research or open new consulting opportunities off campus. An adequate internal reward system was recognized for faculty choosing to remain at the college, but questions were raised in the survey about the marketability of program faculty who opt to leave the college. Seemingly, in the opinion of respondents, the program is well designed to improve teaching performance but not to promote activities that are more exportable, such as research and consulting.

The question arises whether this perceived trade off will continue as the integrated curriculum approach matures at the college. It was expected that faculty professional benefits would be limited and 
opportunity costs would be high during the early years of program delivery. However, the expectation is that faculty benefits will increase (e.g. new interdisciplinary research opportunities) and high opportunity costs (e.g. lengthy coordination meetings) will diminish over time as both program faculty and students ride down the proverbial learning curve.

\section{Conclusions}

One unfortunate byproduct of systemic curriculum reform in any area of higher education is that energies can be dissipated by the time consuming nature of program planning and design. Unfortunately, when new programs are finally launched, little energy may be left to promote the equally important initiative of program assessment.

Babson College has been typical in allocating more time to new program planning and design than to post-launch assessment. However, some assessment data, in the form of student and faculty surveys, are now available to weigh the relative benefits and costs of the college's efforts to integrate the teaching of the undergraduate management core.

The designing and delivery of an undergraduate management core program that effectively integrates across traditional functional disciplines can be viewed as a high risk, high return undertaking. Some risks and costs accrue to students, as the survey data examined in this paper reveals. However, the highest risks and highest opportunity costs seem to accrue to faculty. The degree of difficulty of assuming teaching responsibilities beyond the comfort of one's discipline and of making pedagogical commitments that disrupt (at least temporarily) the flow of disciplinary research can translate into an obstacle to innovation.

Beyond the planning phase, it is expected that opportunity costs for faculty involvement should remain high during the early years of program delivery, albeit at a diminishing rate. There is a significant learning curve effect here as the need for out-of-class coordination meetings decreases over time, as the level of comfort in teaching beyond traditional disciplinary boundaries increases, and as new interdisciplinary collaborations in research and consulting emerge. The benefits of the program, accruing to faculty as well as to students and the college in general (at least in terms of reputation and image), should become more visible so innovative initiatives mature.

Accordingly, if program benefits increase and as the opportunity costs of program participation diminish, it should become progressively easier to retain the services of veteran faculty and to recruit replacements. Although logical, this is little more than speculation, requiring the systematic gathering of hard data and an evidence base. Innovative curricula reforms require regular monitoring. The data examined in this paper presents a snapshot at one point in time. Appropriate program assessments should be ongoing, not occasional, and procedures should be both internal and external. In reference to the latter, full and open examinations and evaluations of curricula reforms and innovations in journals of higher education are an invaluable part of this process. 


\section{Appendix}

Table 1

Understanding the Concepts

As a result of IMC1, I feel that I understand and retained the concepts listed below and will be able to apply them in future classes or jobs:

\begin{tabular}{|l|l|l|l|l|l|}
\hline Topic & $\begin{array}{l}\text { Strongly } \\
\text { agree }\end{array}$ & Agree & Neutral & Disagree & $\begin{array}{l}\text { Strongly } \\
\text { disagree }\end{array}$ \\
\hline Organizational culture & 25 & 63 & 8 & 3 & 1 \\
\hline Individual behavioral styles & 45 & 45 & 7 & 2 & 1 \\
\hline Operations strategy & 16 & 47 & 28 & 7 & 2 \\
\hline The value concept & 15 & 48 & 29 & 5 & 3 \\
\hline Value network/value chain & 22 & 40 & 29 & 5 & 4 \\
\hline Product life cycle & 33 & 49 & 15 & 1 & 1 \\
\hline Product-process matrix & 11 & 34 & 28 & 24 & 3 \\
\hline Service processes & 8 & 39 & 31 & 18 & 4 \\
\hline $\begin{array}{l}\text { Reading and analyzing financial statements of a public } \\
\text { company }\end{array}$ & 28 & 46 & 16 & 8 & 2 \\
\hline $\begin{array}{l}\text { Development of forecasted financial statements and } \\
\text { the ability to do sensitivity analysis on the statements }\end{array}$ & 22 & 49 & 17 & 9 & 3 \\
\hline $\begin{array}{l}\text { Understanding the sources of financing available to } \\
\text { companies }\end{array}$ & 22 & 51 & 13 & 9 & 5 \\
\hline Recording of transactions & 39 & 47 & 9 & 3 & 1 \\
\hline Preparation of balance sheets and income statements & 55 & 36 & 5 & 3 & 1 \\
\hline Preparation of cash flow statements & 46 & 42 & 7 & 4 & 1 \\
\hline Ratio and sensitivity analysis & 22 & 44 & 25 & 8 & 1 \\
\hline $\begin{array}{l}\text { Supply and demand, and the factors that influence } \\
\text { them }\end{array}$ & 43 & 49 & 3 & 3 & 2 \\
\hline Theories of consumer behavior & 18 & 55 & 16 & 8 & 3 \\
\hline Application of Porter's Five Forces & 52 & 38 & 2 & 5 & 3 \\
\hline $\begin{array}{l}\text { Understanding of economic forces and factors that } \\
\text { govern costs in a firm's short and long term earning } \\
\text { operations }\end{array}$ & 20 & 43 & 22 & 9 & 6 \\
\hline Identification of market structural differences & 34 & 48 & 14 & 2 & 2 \\
\hline Segmenting and target market assessment & 38 & 53 & 5 & 3 & 1 \\
\hline Market positioning & 37 & 52 & 9 & 1 & 1 \\
\hline New product development & 33 & 56 & 8 & 1 & 2 \\
\hline Product life cycle & 40 & 49 & 7 & 1 & 2 \\
\hline How to make product pricing decisions & 14 & 45 & 28 & 9 & 2 \\
\hline How to make channel decisions & & & 9 & 4 \\
\hline
\end{tabular}

Note: This survey is based on 102 student responses. Some students were selective in providing answers. 
Table 2

Process and Effectiveness of Integrated Work

\begin{tabular}{|l|l|l|l|l|l|}
\hline Topic & $\begin{array}{l}\text { Strongly } \\
\text { agree }\end{array}$ & Agree & Neutral & Disagree & $\begin{array}{l}\text { Strongly } \\
\text { disagree }\end{array}$ \\
\hline $\begin{array}{l}\text { IMC1 increased my understanding of the relationships } \\
\text { and links among management disciplines. }\end{array}$ & 22 & 61 & 9 & 5 & 2 \\
\hline $\begin{array}{l}\text { IMC1 increased my ability to address } \\
\text { multidisciplinary management issues. }\end{array}$ & 20 & 65 & 10 & 0 & 4 \\
\hline $\begin{array}{l}\text { IMC1 promoted and enhanced my ability to identify, } \\
\text { describe and summarize complex material about } \\
\text { organizations, people and the process in a logical and } \\
\text { useful manner. }\end{array}$ & 17 & 58 & 17 & 4 & 1 \\
\hline $\begin{array}{l}\text { The program case work seemed to be a realistic } \\
\text { portrayal of the issues and opportunities found in } \\
\text { business today. }\end{array}$ & 6 & 27 & 26 & 20 & 21 \\
\hline $\begin{array}{l}\text { Overall, I found the program case work to be a } \\
\text { worthwhile learning experience. }\end{array}$ & 5 & 20 & 17 & 27 & 31 \\
\hline
\end{tabular}

Note: Based on 102 student responses.

Table 3

Preparedness for the Future

\begin{tabular}{|l|l|l|l|l|l|}
\hline Topic & $\begin{array}{l}\text { Strongly } \\
\text { agree }\end{array}$ & Agree & Neutral & Disagree & $\begin{array}{l}\text { Strongly } \\
\text { disagree }\end{array}$ \\
\hline IMC1 adequately prepared me for IMC2. & 18 & 59 & 16 & 5 & 2 \\
\hline $\begin{array}{l}\text { I feel that I will be able to apply what I learned in } \\
\text { IMC1 in a future career or internship. }\end{array}$ & 25 & 56 & 16 & 0 & 3 \\
\hline $\begin{array}{l}\text { IMC1 allowed me to form useful relationships with } \\
\text { faculty members. }\end{array}$ & 18 & 34 & 28 & 18 & 2 \\
\hline
\end{tabular}

Note: Based on 102 student responses. 
Table 4

\section{Relevance to Competencies}

IMC1 contributed to my Babson education by increasing my abilities in the following competency areas:

\begin{tabular}{|l|l|l|l|l|l|}
\hline Topic & $\begin{array}{l}\text { Strongly } \\
\text { agree }\end{array}$ & Agree & Neutral & Disagree & $\begin{array}{l}\text { Strongly } \\
\text { disagree }\end{array}$ \\
\hline $\begin{array}{l}\text { Understanding that ethics is an integral feature of all } \\
\text { personal, social, legal and professional considerations. }\end{array}$ & 10 & 48 & 19 & 17 & 6 \\
\hline $\begin{array}{l}\text { Becoming an active listener and reader, able to } \\
\text { organize, synthesize, evaluate, interrogate and } \\
\text { interpret information of all kinds. }\end{array}$ & 18 & 58 & 19 & 3 & 2 \\
\hline $\begin{array}{l}\text { Enriching my consciousness of international and } \\
\text { multicultural perspectives and experiences. }\end{array}$ & 10 & 25 & 28 & 26 & 10 \\
\hline $\begin{array}{l}\text { Ability to formulate problems, identify opportunities, } \\
\text { construct and test hypothesis, and apply and extend } \\
\text { theory. }\end{array}$ & 10 & 44 & 37 & 4 & 5 \\
\hline $\begin{array}{l}\text { Ability to establish criteria, discover and weigh } \\
\text { alternatives and use appropriate data to arrive at } \\
\text { rational decisions. }\end{array}$ & 9 & 57 & 25 & 7 & 2 \\
\hline $\begin{array}{l}\text { Becoming more comfortable with the creative process } \\
\text { and dealing with ambiguity }\end{array}$ & 10 & 45 & 27 & 14 & 4 \\
\hline $\begin{array}{l}\text { Becoming more adept at working in teams to } \\
\text { accomplish common goals, exercising appropriate } \\
\text { leadership and negotiating differences. }\end{array}$ & 32 & 56 & 11 & 0 & 1 \\
\hline $\begin{array}{l}\text { Communicating logically and persuasively in spoken, } \\
\text { written and visual form. }\end{array}$ & 18 & 54 & 20 & 5 & 2 \\
\hline $\begin{array}{l}\text { Appreciating the challenges of balancing home, work, } \\
\text { recreation and community service. }\end{array}$ & 20 & 40 & 15 & 11 & 13 \\
\hline $\begin{array}{l}\text { Becoming more familiar with technology and its } \\
\text { impact on the business environment. }\end{array}$ & 16 & 38 & 25 & 14 & 7 \\
\hline $\begin{array}{l}\text { Increasing my ability to bring a high level of business } \\
\text { expertise to a workplace and society. }\end{array}$ & 21 & 58 & 14 & 4 & 3 \\
\hline
\end{tabular}

Note: Based on 102 student responses. 
Table 5

Faculty Perceptions of Program Costs and Benefits for Students

Based on my experience teaching IMC1, I would conclude that this integrated program:

\begin{tabular}{|l|l|l|l|l|l|}
\hline Topic & $\begin{array}{l}\text { Strongly } \\
\text { agree }\end{array}$ & Agree & Neutral & Disagree & $\begin{array}{l}\text { Strongly } \\
\text { disagree }\end{array}$ \\
\hline $\begin{array}{l}\text { Has effectively prepared students for the upper-level } \\
\text { study of management. }\end{array}$ & 5 & 10 & 2 & 2 & 0 \\
\hline $\begin{array}{l}\text { Has closely mirrored actual conditions and decision- } \\
\text { making processes in the business world. }\end{array}$ & 3 & 15 & 1 & 0 & 0 \\
\hline $\begin{array}{l}\text { Has effectively prepared students for entry level } \\
\text { positions in business. }\end{array}$ & 4 & 9 & 3 & 2 & 0 \\
\hline $\begin{array}{l}\text { Has proven to be an effective way of teaching } \\
\text { functional skills. }\end{array}$ & 5 & 8 & 2 & 3 & 1 \\
\hline $\begin{array}{l}\text { Has demonstrated to students the important linkages } \\
\text { and interrelationships among the management } \\
\text { disciplines. }\end{array}$ & 8 & 7 & 3 & 1 & 0 \\
\hline $\begin{array}{l}\text { Has succeeded in standardizing the labels and } \\
\text { language used in different disciplines for the same } \\
\text { concepts. }\end{array}$ & 4 & 4 & 8 & 2 & 1 \\
\hline Is well designed to teach decision-making skills. & 2 & 5 & 7 & 5 & 0 \\
\hline $\begin{array}{l}\text { Does not contain significant undesirable curriculum } \\
\text { redundancy and overlap. }\end{array}$ & 1 & 12 & 2 & 3 & 1 \\
\hline $\begin{array}{l}\text { Does not fragment the delivery of the core, reducing } \\
\text { student comprehension. }\end{array}$ & 3 & 7 & 2 & 7 & 0 \\
\hline $\begin{array}{l}\text { Does not fragment the delivery of the core, } \\
\text { discouraging the healthy development of } \\
\text { student/faculty relationships. }\end{array}$ & 4 & 7 & 4 & 2 & 2 \\
\hline $\begin{array}{l}\text { Has not reduced the popularity of management core } \\
\text { disciplines in the view of the students. }\end{array}$ & 4 & 10 & 2 & 3 & 0 \\
\hline
\end{tabular}

Note: Based on 19 faculty responses. 
Table 6

Faculty Perceptions of Program Costs and Benefits for Faculty

Based on my experience teaching IMC1, I would conclude that this integrated program:

\begin{tabular}{|l|l|l|l|l|l|}
\hline Topic & $\begin{array}{l}\text { Strongly } \\
\text { agree }\end{array}$ & Agree & Neutral & Disagree & $\begin{array}{l}\text { Strongly } \\
\text { disagree }\end{array}$ \\
\hline $\begin{array}{l}\text { Has been a valuable learning experience for me by } \\
\text { expanding my responsibilities beyond the normal } \\
\text { boundaries of my discipline }\end{array}$ & 9 & 5 & 2 & 3 & 0 \\
\hline $\begin{array}{l}\text { Has provided me with fresh insights about the role of } \\
\text { my discipline in the undergraduate business curriculum. }\end{array}$ & 7 & 3 & 6 & 3 & 0 \\
\hline $\begin{array}{l}\text { Has improved my teaching of upper-level courses in my } \\
\text { discipline by providing an overall curriculum overview. }\end{array}$ & 7 & 5 & 4 & 3 & 0 \\
\hline $\begin{array}{l}\text { Has improved my ability to interact with students based } \\
\text { on my better understanding of the total curriculum. }\end{array}$ & 5 & 6 & 4 & 3 & 1 \\
\hline $\begin{array}{l}\text { Has improved my teaching through program exposure } \\
\text { to pedagogical styles and skills practiced in other } \\
\text { disciplines. }\end{array}$ & 6 & 8 & 3 & 2 & 0 \\
\hline $\begin{array}{l}\text { Has created new opportunities for me to participate in } \\
\text { cross disciplinary research collaboration. }\end{array}$ & 3 & 4 & 9 & 2 & 1 \\
\hline Has spurred my productivity in research. & 1 & 3 & 8 & 4 & 3 \\
\hline $\begin{array}{l}\text { Has opened new consulting opportunities for me off } \\
\text { campus. }\end{array}$ & 0 & 0 & 5 & 8 & 6 \\
\hline $\begin{array}{l}\text { Has promoted my marketability if in the future I decide } \\
\text { to leave the college. }\end{array}$ & 3 & 1 & 6 & 5 & 4 \\
\hline $\begin{array}{l}\text { Has been instrumental in supporting my internal } \\
\text { advancement, e.g. in reference to tenure, promotion, } \\
\text { salary raises, etc. }\end{array}$ & 3 & 6 & 4 & 4 & 2 \\
\hline $\begin{array}{l}\text { Has not required a heavier time commitment in } \\
\text { preparing and delivering teaching materials than in the } \\
\text { case of my traditional courses. }\end{array}$ & 2 & 7 & 4 & 2 & 4 \\
\hline $\begin{array}{l}\text { Has not required a heavier time commitment in out-of- } \\
\text { class coordination activities. }\end{array}$ & 1 & 2 & 5 & 6 & 5 \\
\hline
\end{tabular}

Note: Based on 19 faculty responses. 


\section{References}

American Assembly of Collegiate Schools of Business. (1995). MBA Program Changes Prove Value Does Not Come Cheaply. Newsline, 26: 1-6.

Axarloglou, K., Casey, W., Dhebar, A., Fiske, C., Gwin, C., Walshli, S. \& Wright, F. (1999). Intermediate management core: Understanding the firm and the market. New York: McGraw Hill.

Babson College Undergraduate Catalog, 1999-2000.

Bliss, R.T. \& Potter, M.E. (2000). Integrating the undergraduate business curriculum: The case of Babson College. Journal of Business Education, 76, 1-13.

Boyatzis, R.E., Cowen, S.S., \& Kolb, D.A. (1995). Innovation in professional education: Steps on a journey from teaching to learning. San Francisco: Jossey-Bass Inc.

Boyer, E.L. (1990). Scholarship reconsidered. Princeton, NJ: Carnegie Foundation.

Dodd, N.G., Brown, F.W., \& Benham, H. (2002). Learning to manage while learning about management: A transition to a competency-based management curriculum. Journal of Education for Business, 77, 189-192.

Elliott, C.J., Goodwin, J.S., \& Goodwin, J.C. (1994). MBA programs and business needs: Is there a mismatch? Business Horizons, 37, 55-60.

Geiger, J.J. \& Dangerfield, B.J. (1996, November). An analysis of integrated curriculum models in U.S. colleges of business. Proceedings of the Decision Sciences Institute Annual Meeting. Atlanta, Georgia: Decision Sciences Institute.

Harrigan, K.R. (1990). Professionalism in management education: Is the emperor naked in the 1990s? Academy of Management Review, 15, 696-698.

Hartenian, L.S., Schellenger, M., \& Frederickson, P. (2001). Creation and assessment of an integrated business course: One college’s experience. Journal of Education for Business, 76,149-159.

Lancaster, K.J. (1966). A new approach to consumer theory. Journal of Political Economy, 74,132-57.

Latham, G., Latham, S. D., \& Whyte, G. (2004). Fostering integrative thinking: Adapting the executive education model to the MBA program. Journal of Management Education, 28, 3-18.

McKinney, E. H. \& Yoos, C.J. (1998). The one room school house: An information and learning approach to curriculum integration. Journal of Management Education, 22, 618-636.

McLeod, P.L. \& Cotter, J.E. (1999). Opposites may not attract, but they can complement: Integrating finance and organizational behavior in the MBA curriculum. Journal of Management Education, 23, 251-262. 
Miller, J.R. (2000). Economics in the integrated business curriculum. Journal of Education for Business, $76,113-118$.

Palocsay, S.W., White, M.M., \& Zimmerman, D.K. (2004). Interdisciplinary collaborative learning: Using decision analysts to enhance undergraduate international management education. Journal of Management Education, 28, 250-259.

Pharr, S. W. (2000). Foundational considerations for establishing an integrated business common core curriculum. Journal of Education for Business, 76, 20-23.

Porter, L.W. (1997). A decade of change in the business school: From complacency to tomorrow. Selections, 13, 1-8.

Porter, L.W. \& McKibbin, L.E. (1988). Management education and development: Drift or thrust into the $21^{\text {st }}$ century? New York: McGraw-Hill.

Porter, M. (1979). How competitive forces shape strategy. Harvard Business Review, 57, 137-145.

Schlesinger, P.F. (1996). Teaching and evaluation in an integrated curriculum. Journal of Management Education, 20, 479-499.

Slater, J.S., McCubbrey, D.J., \& Scudder, R.A. (1995). Inside an integrated MBA: An information systems view. MIS Quarterly, 19, 391-410.

Van Fleet, D. D. (1995). Designing MBA programs with students in mind. Journal of Management Education, 19, 373-379.

Zolner, J. P. (1996). Moving the academic graveyard: The dynamics of curricular change. Selections, 12, $1-10$. 
